\title{
Ontogenetic changes in the ostracod Cytherella cf. ovata Roemer, from the Cenomanian of Algeria
}

\author{
STEFAN MAJORAN \\ Paleontologiska Institutionen, Uppsala Universitet, Box 558, S-751 22 Uppsala, Sweden
}

\begin{abstract}
Cytherella cf. ovata Roemer, were selected from a single sample of Cenomanian age (northeastern Algeria). The material can be subdivided into two parallel ontogenetic series which were quantitatively investigated by linear regression and eigenshape analysis. The corresponding growth stages of the two series are differentiated by size, growth rate, and, to a lesser extent, by shape. The relationship between the two series are discussed mainly in terms of seasonal variation in the environment.
\end{abstract}

\section{INTRODUCTION}

Fossil representatives of the ostracod genus Cytherella are particularly difficult to assess at the species level. The preserved shells are smooth and featureless, leaving only size and shape to serve as foundations for systematic classification, a tough constraint since these characters on several occasions have been documented as highly variable within ostracod species (Reyment, 1963, 1966, 1988), and specifically within species of Cytherella (cf. Ducasse, 1981).

Even when opinions are formed on which specimens in a specific sample are to be grouped together, one still has to face difficulties when it comes to naming them. Some of the categories may show similarities with already described taxa; this constantly induces the taxonomist into the awkward situation of opting arbitrarily between placing the specimens under available names, erecting new ones, or referring the specimens to Cytherella spp. (cf. Reyment, 1984).

No further speculation is proposed for the general problems surrounding Cytherella, as this is not the object of this paper, but attention is directed to some specimens referred to Cytherella cf. ovata Roemer, by Majoran (1989). A more precise determination is presently impossible due to the difficulties outlined above. These specimens are from a single sample obtained from a road-section some $5 \mathrm{~km}$ south of the village of Bordj Ghdir (Fig. 1), northeastern Algeria. The section, which is located on the north side of the central part of the mountain chain of Hodna (lat. $35^{\circ} 52^{\prime} \mathrm{N}$, Long. $4^{\circ}$ $55^{\prime} \mathrm{E}$ ), was described by Majoran (1989). The sample is Early Cenomanian in age and labelled A12 by Majoran (1989).

Discrete morphological variants among the specimens were not recognised by Majoran (1989), other than sexual dimorphism. In the present more detailed investigation, however, an inspection of some 200 well preserved right valves, comprising 6 ontogenetic stages, has brought about a subdivision of the material into two parallel ontogenetic series differentiated mainly by the average-size and the shape of the carapaces. The shape difference is mainly manifested along the posteroventral periphery (Plate 1). The object of

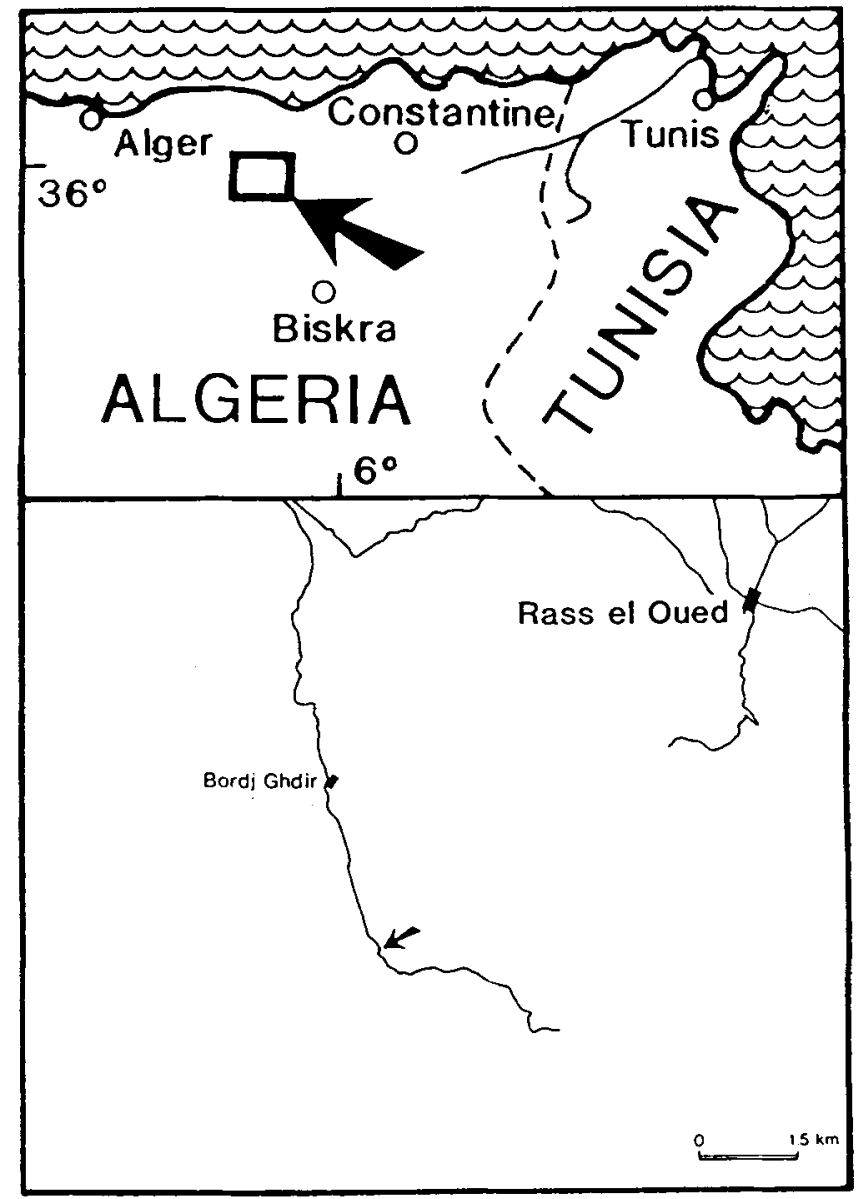

Fig. 1. Map showing the location of the Bordj Ghdir section (indicated by arrow).

this study is to discuss the relationship between the two series in the view of a statistical description of the associated size and shape differences. The statistical methods used are linear regression and eigenshape analysis (Lohmann, 1983)

The reason for restricting this investigation to a single 
sample is to limit, as far as possible, the underlying sources of variation to just seasonal variation. Abe (1983) investigated the marine ostracod Keijella bisanensis (Okubo) and found variation in the average-length of the carapace directly related to seasonal changes. It is important to point out that contemporaneous variation in sea-water chemistry and temperature may affect size as well as omamental details of the shells of marine ostracods (cf. Reyment et. al, 1988)

\section{METHODS OF STUDY}

The specimens were grouped together by growth stage. Two kinds of ontogenetic change in the carapace of $C y$ therella cf. ovata were examined, size and shape. Size, which is the area enclosed by the outline of the carapace, was determined by rapid image digitization. The measurements were then logarithmically transformed because of allometric growth effects and because a nonlinear measure of size was used (cf. Maness \& Kaesler, 1987, p.3), and then regressed on growth stage in order to determine the growth rate, i.e. size increase in relation to instar number. Shape changes were studied by eigenshape analysis (Lohmann, 1983), a method that may take advantage of rapid image digitization and has the advantage of describing shape independently of size. The
Table 1. Number of specimens in each growth stage measured.

\begin{tabular}{lcc}
\hline Growth Stage & Greater size-class & Smaller size-class \\
\hline Adult & 20 & 40 \\
A-1 & 25 & 37 \\
A-2 & 15 & 22 \\
A-3 & 3 & 12 \\
A-4 & 7 & 4 \\
A-5 & 8 & 3 \\
& 78 & 118 \\
Total & 718 \\
\hline
\end{tabular}

input data consist of coordinate pairs that are equally spaced around the outline of the carapaces (see below).

\section{REMARKS ON THE SUBDIVISION}

In the present investigation, the length was originally plotted against the logarithmically transformed area (Fig. 3); this produced broad, but quite clearly differentiated clusters. Only the segregation between the adult and the A-1 stage appears somewhat ambiguous. However, according to Fig. 3,
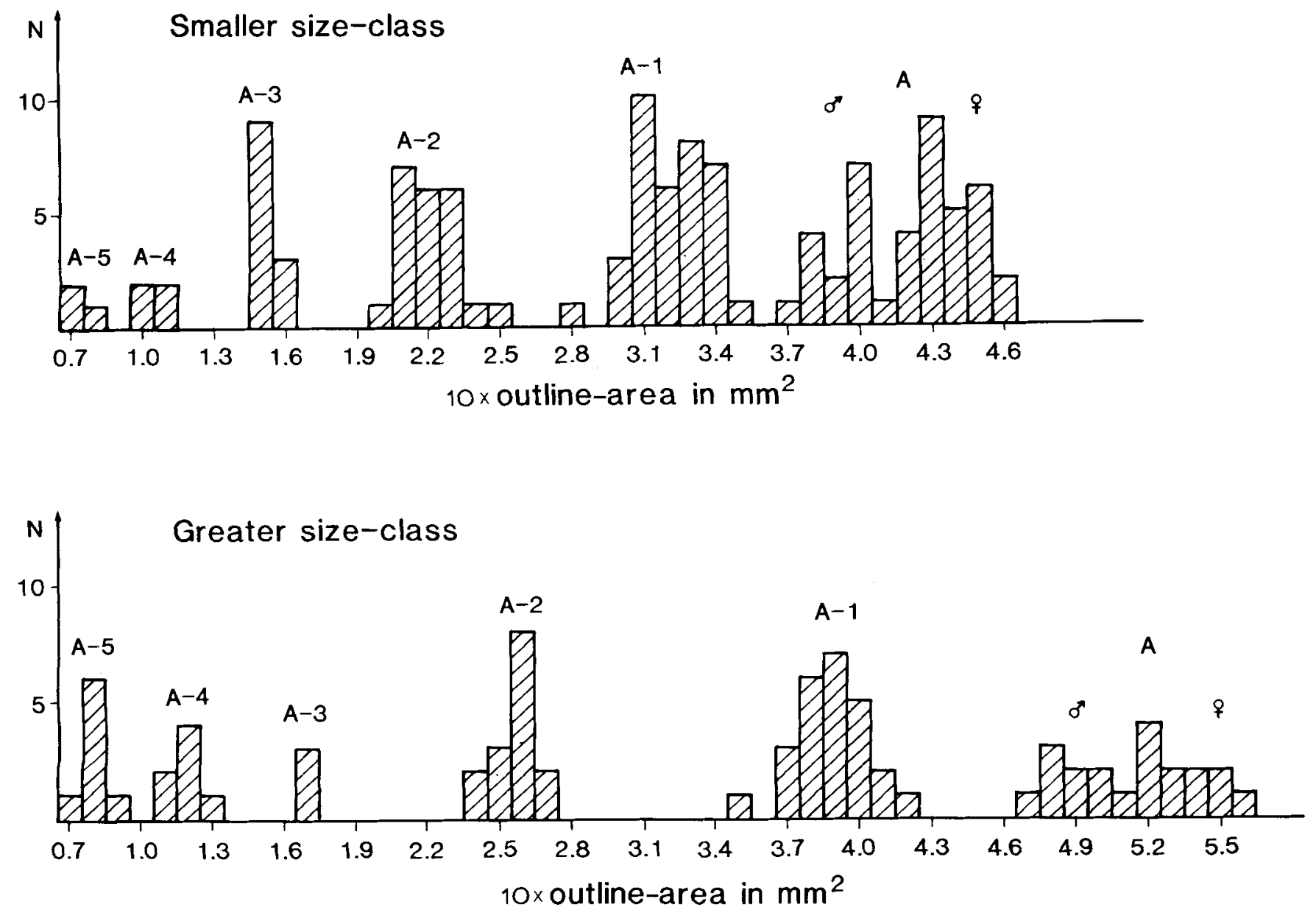

Fig. 2. Cytherella cf. ovata. Size frequency histograms for each of the two-size classes. 


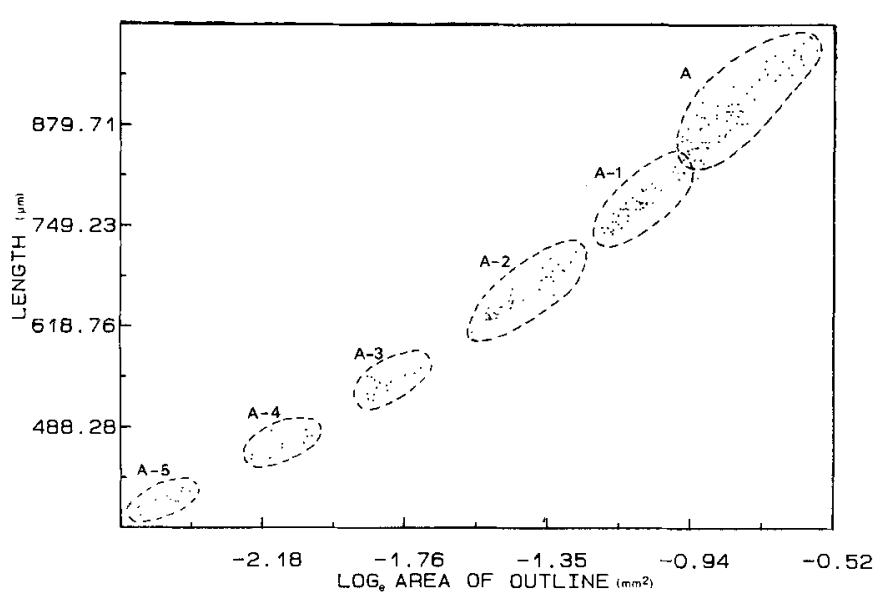

Fig. 3. Cytherella cf. ovata. Plot of area of outline against length, all growth stages (A-5 to A) of both size-classes together.

the scatter of the individuals within the different clusters shows some bimodality for the A-4, A-3 and A-2 stages, a phenomenon which supports a segregation into two sizeclasses. Furthermore, the differentiation can be based also on minor shape differences that appear consistently throughout all growth stages observed. In this connection, it seems less likely that, for example, the specimens referred to as adults of the small size-class actually represent a sexually dimorphic (precocious) A-l stage of the larger size-class.

\section{EIGENSHAPE ANALYSIS}

Eigenshape analysis is a technique that derives essentially a set of empirical orthogonal shape functions by a principal component analysis of a matrix of correlations between shapes (Lohmann, 1983). Schweitzer et.al (1986) and Maness \& Kaesler (1987) applied this method to ostracods in the same sense as intended here. Although the procedure of Lohmann (1983) is largely followed, a brief review of his method is given here in order to elucidate the details associated with this particular investigation.

The first stage in the analysis is to digitize points along the outline of the specimens in order to record their Cartesian coordinates, preferably by a microprocessor-controlled video image digitizer. Each outline is then interpolated into 30 segments, a small number in relation to the recommendations of Lohmann (1983), but sufficient enough for the simple outline of Cytherella. The next step is to transform the digitized coordinates to shape descriptor functions, in this case to size independent, normalized phi-star functions of Zahn \& Roskies (1972); these represent the normalized net angular bend at each step around the outline of each specimen digitized. However, to be able to compare shapes among different specimens, it is important to use some kind of homologous starting point and digitize landmarks that are homologous from form to form. On Cytherella, there are no landmarks, so it is only possible to compare homologous regions of the outline, as was also the case in the practical application given by Lohmann (1983). In practice, this requires selecting a single specimen as reference shape and orienting the other specimens as consistently as possible with respect to it. Admittedly, such a procedure can only be approximate.

Once the specimens are represented by a collection of comparable, normalized phi-star functions, each being a column vector consisting of 30 variables, the eigenshapes are computed as principal components from the correlation matrix of these shape functions (Lohmann, 1983). Only the first few eigenshapes are interpretable. The first eigenshape is generally interpreted as the general sheared or average shape, and all specimens are positively correlated with it, whereas subsequent eigenshapes represent contrast in shape (Lohmann, 1983; Schweitzer et al., 1986).

In order to quantify shape change between different ontogenetic stages, it is preferable to group the specimens by growth stage and perform a separate eigenshape analysis for each group. Each group is then to be represented by the corresponding first eigenshape in order to minimize withinsource variation and metric error. Between group variation is subsequently determined by an additional eigenshape analysis of the first eigenshape of each growth stage. Most of the shape change between the different categories is shown by the second and third eigenshapes of this final eigenshape analysis (Lohmann, 1983; Schweitzer et al., 1986; Maness \& Kaesler, 1987).

\section{ONTOGENETIC SIZE CHANGE}

After being logarithmically transformed, the size data were regressed on growth stage, one regression for each of the two size-classes $(\mathrm{N} 1=78, \mathrm{~N} 2=118)$. The two regression lines were compared and examined to see if they differ in any manner (cf. Williams, 1984, pp. 315-319). First, the estimates of scatter of the data points about the regression lines were examined by comparing the corresponding squared standard errors using an ordinary two-tailed F-test. This yielded a value which just failed to reach the tabulated $5 \%$ value for $\mathrm{N} 1$ 2 and N2-2 degrees of freedom. Thus, the squared standard errors of the variance are not regarded as significantly different. A pooled estimate of the common variance was calculated $(\mathrm{S}=0.16)$.

In order to compare the slopes of the two regression lines, the estimated standard error of the difference between the regression coefficients was calculated (cf. Williams, 1984, p. 321) yielding a value of $t=4.61$ which is significant at $P=0.00001$. Thus, the two regression lines can be regarded as having different slopes; consequently, there is little point in testing whether the intercepts of the two lines are significantly different. The regression coefficient $\mathrm{B}$ for $\mathrm{Y}=\mathrm{BX}+\mathrm{A}$; is 2.95 for the greater size-class and 2.73 for the smaller size-class.

Fowler (1909) claimed that each growth stage of an ostracod species differs from the previous growth stage by increasing its length by a fixed percentage, and that this percentage is constant for all growth stages of a species. Fowler (1909) termed this Brook's law and formulated it as $\mathrm{L}(\mathrm{n}+1)=\mathrm{KL}(\mathrm{n})$, 
where $L(n)$ is the length of the carapace at the nth growth stage and $\mathrm{K}$ the growth factor. Anderson (1964) critically appraised Fowler's theories and found several species with growth increments that were inconsistent with Brook's law. Taking into account our observations on Cytherella cf. ovata, it is obvious that Brook's law cannot be applied to our areal increments from one growth stage to the next. Although it may be true to say that ostracods roughly double their volume between subsequent growth stages (Przibram, 1931), it is less likely to find a precise agreement when comparing the increase of a single parameter such as length or height, between as well within species (Kesling, 1952; Anderson, 1964).

From this investigation, it can be concluded that the points distributed around the two regression lines do not have a significantly different degree of scatter despite differences with respect to the growth rate as reflected by the regression coefficients.

Hutchinson's rule (cf. van Harten, 1983) states that species that differ only in size seem to require that the larger be about twice as heavy as the smaller in order for them to coexist, is not followed in this case. Thus, if the rule is correct and size is considered independently, it cannot be inferred that the two size-classes represent two separate species.

\section{ONTOGENETIC SHAPE CHANGE}

The material includes two size-classes with 6 ontogenetic stages, giving a total of 12 categories. Each of these groups was subjected to a separate eigenshape analysis, in order to obtain a representative outline for each group (first eigenshape) and to examine the variation within each category when the second and third eigenshapes are plotted against each other. There is almost no nonrandom variation; only a few outliers had to be removed from one of the plots. Thus, the first eigenshapes can be regarded as representative outlines (Maness \& Kaesler, 1987)

Although sexual dimorphism is manifested among the adults of both size-classes in the average-size and the inflation of the posterior region of the carapace, plots of the second and third eigenshapes against each other simply disclose a slight segregation. Therefore, the two sexes were not separated in the subsequent analysis, although some information is probably lost because of this.

To enable comparison among the 12 growth categories recorded, the first eigenshapes were selected as representative outlines and subjected to an additional eigenshape analysis (cf. Schweitzer et al., 1986; Maness \& Kaesler, 1987). The first eigenshape of this analysis represents the general or shared shape and accounts for $96 \%$ of the total variation, a high value that indicates a close agreement in shape among the instars. The second eigenshape, which represents the major contrast in shape, accounts for $2.2 \%$ of the total variation, and is the only one of interpretable significance. Subsequent eigenshapes cannot be given any interpretation since the associated eigenvalues are too small $(<0.6 \%)$.

The 12 growth categories are plotted in the plane of the second eigenshape and their logarithmically transformed areal measure (Fig. 4). There is a great shape difference between the A-5 stage of the two size-classes; then the shapes converge and are nearly the same for the next two stages. The smaller size-class shows shape change from the A-3 to the A2 stage and then a reverse change from the A-2 to the A-1 stage. The larger size-class shows shape change from the A2 to the A-1 stage. Both size-classes show approximately no shape change from the A-1 to the adult stage which comprises both males and females (Fig. 4).

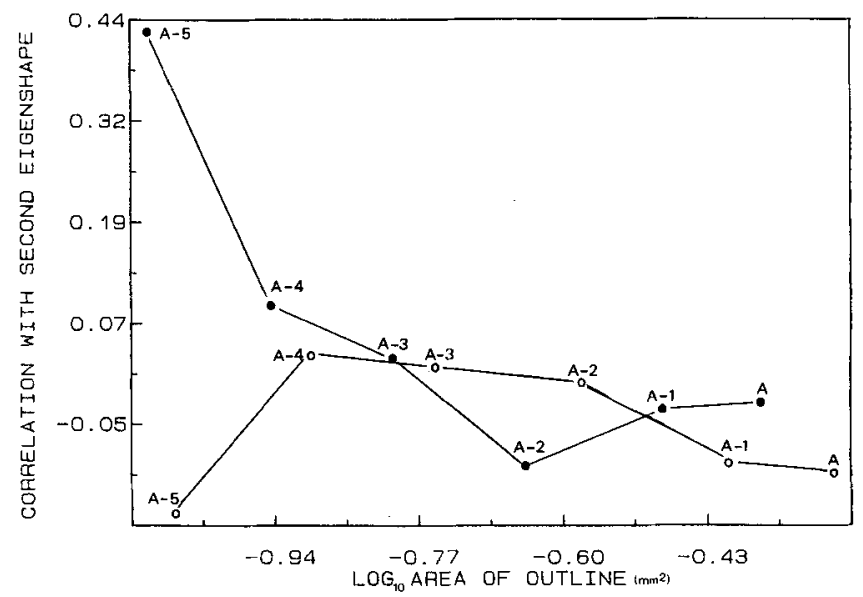

Fig. 4. Cytherella cf. ovata. Ontogenetic variation in size and shape, both size-classes included. The correlation with the second eigenshape summarizes the major contrast in shape among instars.

\section{DISCUSSION}

Before discussing the significance of the statistical results,

\section{Explanation of Plate 1}

All specimens are approximately $x 70$

All specimens are yiew of right valves

Figs. 1-6. Cytherella cf. ovata Roemer. From the Lower Cenomanian of the road-section near Bordj Ghdir, northeastern Algeria. Greater size-class. Six ontogenetic stages (A to A-5). The adult specimen (Fig. 1) is a female. Figs. 1-6: PMAL 230-235. (PMAL: Storage codes for the Palaeontological Museum, Uppsala University).

Figs. 7-12. Cytherella cf. ovata Roemer. From the Lower Cenomanian of the road-section near Bordj Ghdir, northeastern Algeria. Smailer size-class. Six ontogenetic stages (A to A-5). The adult specimen (Fig. 7) is a female. Figs. 7-12.: PMAL 236-241. (PMAL: Storage codes for the Palaeontological Museum, Uppsala University). 


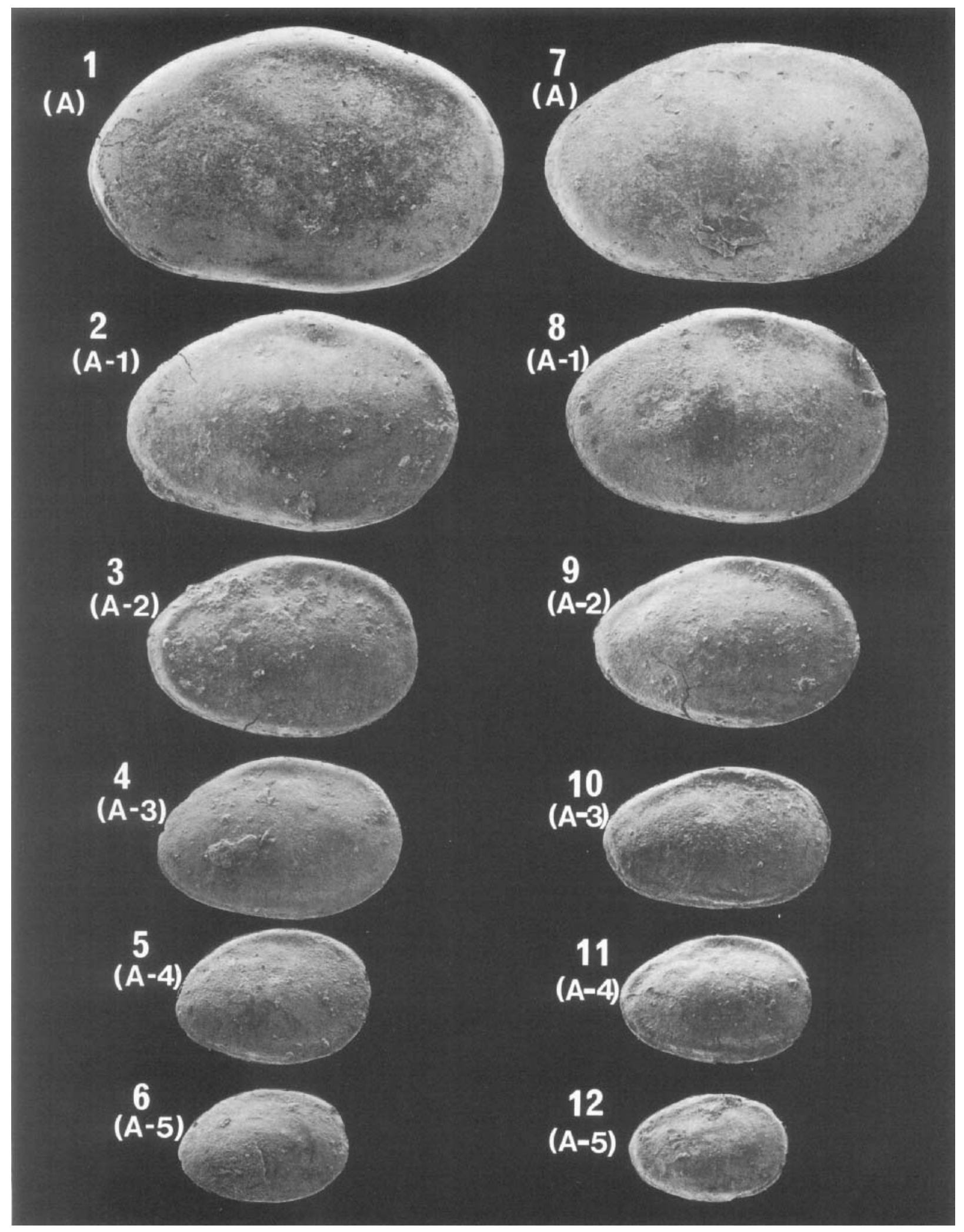


Table 2. Relative abundances of ostracod species recorded from sample A1 2 of the road-section south of BordjGhdir, northeastern Algeria (cf. Majoran, 1989). The significance of the question and quotation marks around some of the generic and species names follow the recommendations of Bengston (1988).

Cytherella cf. ovata Roemer

Pontocyprella sp.

"Cythereis aaramtaensis" Bischoff

Cytherella sulcata? Van Veen

Peloriops ziregensis? (Bassoullet \& Damotte)

Cytherella aff. contracta Van Veen

Centrocythere tunetana Bismuth \& Donze

Bairdia sp.

Bythocypris? sp.

Paracypris dubertreti? Damotte \& Saint-Marc

Eocytheropteron glintzboeckeli Donze \& Lefevre

Cythereis? sp.

Cythereis sp.

"Veeniacythereis" subrectangulata Majoran

Peloriops sp.

"Veeniacythereis streblolophata" Al-Abdul-Razzaq \& Grosdidier

$>30 \%$
$15 \%<30 \%$
$15 \%<30 \%$
$5 \%<15 \%$
$5 \%<15 \%$
$<5 \%$
$<5 \%$
$<5 \%$
$<5 \%$
$<5 \%$
$<5 \%$
$<5 \%$
$<5 \%$
$<5 \%$
$<5 \%$
$<5 \%$

a brief account of the environment in which the present material was deposited is given.

The bed from which the sample was obtained consists of greenish-grey marly clay. The ostracod species recorded are listed in order of abundance in Table 2 . The more abundant species display distributional patterns that imply an autochtonous association in a rather low energy biocoenosis (cf. Whatley, 1983; Majoran, 1989). Another indication of low energy conditions is expressed by more than $50 \%$ closed carapaces among the ostracod. This may, however, also be taken as a sign of a relatively high rate of sedimentation (McKenzie, 1983).

Cytherella cf. ovata, which is the most abundant species belongs to an ubiquitous genus, but its size and morphology point towards a deep, open-marine habitat (Babinot \& Colin 1983; Vivière, 1985). The non-ubiquitous Pontocyprella sp. is also generally regarded as a deep open-marine form, as are Paracypris and Bythocypris (cf. Majoran, 1989). However, trachyleberidids with well developed eye-tubercles are also common. The latter indicates a water depth less than $800 \mathrm{~m}$. Possibly the sample belongs to an open-marine environment beyond the edge of the carbonate platform, associated with an outer shelf or epibathyal slope environment. Many of the cytherellids have pyritized carapaces, a phenomenon that may have been caused by periods of postmortem anoxia.

One possible explanation for short-period, seasonal anoxia is upwelling (McKenzie \& Peypouquet, 1984). Upwelling of cold, nutrient rich water produces increased productivity in the pelagic zone. When the associated plankton bloom dies, there is a seasonal increase in the accumulation of organic matter on the sea floor. As most benthic ostracods are scavengers, they respond by breeding up (McKenzie \& Peypouquet, 1984). At this stage, much of the settled organic matter is insufficiently decomposed by bacterial action; this causes a lowering in $\mathrm{pH}$, a rise in $\mathrm{CO}_{2}$, and a diminished $\mathrm{O}_{2}$ content. Contemporaneously the amounts of dissolved $\mathrm{Mg}^{2+}$ and $\mathrm{Ca}^{2+}$ ions are high. Later the $\mathrm{pH}$ increases producing normally oxygenated conditions, and the $\mathrm{CO}_{2}$ level falls. The dissolved ions $\left(\mathrm{Ca}^{2+}\right.$ and $\left.\mathrm{Mg}^{2+}\right)$ diminish. The $\mathrm{Ca}^{2+}$ react with the $\mathrm{CO}_{2}$ and precipitate.

Fluctuations in the amount of dissolved $\mathrm{Ca}^{2+}$ and $\mathrm{Mg}^{2+}$ ions are known to affect carapace ornament. This is reflected by aggraded or degraded morphs (Peypouquet et al., 1986), an ecophenotypic phenomenon. The effects of aggradation and degradation have been observed in "Veeniacythereis" subrectangulata cf. Table 2 (Majoran, 1988). When upwelling is not evident, a similar phenomenon might be produced by other sources of oxygen variation (cf. Peypouquet et al., 1988).

Peypouquet (1977) has demonstrated that the size of the carapace may vary with the amount of dissolved nutrients. It is well known that seasonal fluctuations in temperature may also affect the average-size of the carapace; however, seasonal fluctuations may also affect the growth rate during ontogeny, according to van Harten (1983). Abe (1983) concluded that carapace size varies more widely in fossils than in living ostracod species partly due to the mixing of shells from different seasons and hence temperatures. Kaesler (1975) found a correlation between carapace size of the fresh-water species Cypridopsis vidua (O. F. Müller) and the amount of such dissolved elements as calcium and magnesium in the water. Laboratory studies of the same species yielded smaller 
average-sizes than normal when the concentration of calcium was abnormally high or the environment stagnant (Reyment \& Brännström, 1962). Neale (1988) has dealt with the correlation between carapace size and salinity in further detail.

The life-cycles of marine podocopid ostracods are either seasonal, i.e. producing one or more generations per year during the warmer seasons and with overwintering eggs, or aseasonal, i.e reproducing continuously throughout the year. Uffenorde (1975) studied the life-cycle of a species of Cytherella and found the whole range of instars throughout the entire year in the Limski Canal, Yugoslavia. If aseasonal reproduction is general for the genus, it is likely to produce great intraspecific size and shape variation, much of which is continuous ecophenotypic variation; however, this does not exclude the occurrence of quasicontinuous threshold phenomena (cf. Reyment, 1988) induced seasonally by critical temperature and chemical barriers. Furthermore, current research (Rossi et al., 1988) indicates that observed seasonal differences in size and shape of reared parthenogenetic populations of the freshwater species Heterocypris incongruens, are correlated with electrophoretic differences in their tissues.

Although the eigenshape analysis discloses slight differences between the two size-classes for the A-4 and subsequent stages (Fig. 4), the nature of the shape differences seems discontinuous as far as can be judged from visual inspection of the specimens. Thus, explanations such as those summarised in the preceding paragraph, may be insufficient. If the comparatively more pronounced differences in the A-5 stages are emphasised (Fig. 4), other explanations are possible.

One possible explanation is due to the fact that some Cytherella are able to retain eggs or earlier instars within the brood-space of the female carapace during times of stress (Elofson, 1941; Horne, 1983), and if this phenomenon affects the shape and the size even on dispersed juveniles, it might explain the more pronounced difference in the A-5 stage as well as the minor differences in subsequent stages.

Another possible explanation is that the differences are due to incipient speciation and that this is only evident statistically by shape in the earlier growth stages. Abe (1988) discussed what he believed to be incipient speciation in Keijella bisanensis, mainly in relation to size-differences, although four different forms were recognised that apart from size can be differentiated also with respect to length: height-ratios. The forms were distributed sympatrically as well as allopatrically. Abe (1988) suggested that the most probable explanation of the origin of the size-differences was polyploidy, although other underlying sources of variation such as heterochrony and geographical variation (within the normal range) were also taken into consideration.

None of the underlying sources of variation proposed by Abe (1988) can directly be excluded as far as the present material is concerned, not even the geographical aspects, because many perspectives of the relationship between these specimens remain unnoticed due to the fact that the chronological and spatial distribution and order of appearance of the two size-classes are largely unknown.

\section{ACKNOWLEDGEMENTS}

I am grateful to Professor R. A. Reyment, Uppsala, and Dr. K. G. McKenzie, Melbourne, for reviewing the manuscript; to Dr.U. Nordlund, Uppsala, for introducing me to his computer program for eigenshape analysis; and to the technical staff of the Institute of Historical Geology and Palaeontology, Uppsala, for preparing drawings and plates.

\section{Manuscript received March 1989 \\ Revised Manuscript accepted October 1989}

\section{REFERENCES}

Abe, K. 1983. Population structure of Keijella bisanensis (Okubo) (Ostracoda, Crustacea).J. Fac. Sci. Univ. Tokyo, 20, 443-488.

Abe, K. 1988. Speciation completed? in Keijella bisanensis species group. In Hanai, T., Noriyuki, I. \& Ishizaki, K. (Eds.), Proceedings of the Ninth International Symposium on Ostracoda. Developments in Palaeontology and Stratigraphy, 11, 919-926. Kodansha, Elsevier.

Anderson, F.W. 1964. The law of ostracod growth. Palaeontology 7, 85-104.

Babinot, J-F. \& Colin J-P. 1983. Marine Late Cretaceous ostracode faunas from southwestern Europe: A paleoecological synthesis. In Maddocks, R.F. (Ed.), Proceedings of the Eighth International Symposium on Ostracoda. Applications of Ostracoda, 182-205. Univ. Houston Geosc. USA.

Bengtson, P. 1988. Open nomenclature. Palueontology, 31, 223-227.

Ducasse, O. 1981. Etude populationniste du genre Cytherella (Ostracodes) dans les facies du Paléogène aquitaine. Intérêt dans la reconstitution de paléonenvironments. Bull. Inst. Géol Bassin d'Aquitaine, Bordeaux, 30, 161-186.

Elofson, O. 1941. Zur Kenntnis der marinen Ostracoden Schwedens mit besonderer Beruicksichtigung des Skageraks. Zoologiska bidrag fran Uppsala, 19, 215-334.

Fowler, G. H. 1909. The Ostracoda. Biscayan Plankton, Pt. 12. Trans. Linn, Soc. London (Zool.), 10, 219-336.

Horne, D. J. 1983. Life-cycles of prodocopid Ostracoda - A review (with particular reference to marine and brackishwater species). In Maddocks, R.F. (Ed.), Proceedings of the Eighth International Symposium on Ostracoda. Applications of Ostracoda, 581-590. Univ. Houston Geosc. USA.

Kaesler, R. L. 1975. Morphology of Cypridopsis vidua (O. F. Müller): Variation with environment. Bulletins of American Paleontology, 65, 225-244.

Kesling, R. V. 1952. Doubling in size of ostracod carapaces in each molt stage. J. Paleont., 26, 772-780.

Lohmann, G. P. 1983. Eigenshape analysis of microfossils: a general morphometric procedure for describing changes of shape. Math. Geol., 15. 659-672.

Majoran, S. 1988. Comments on a miscellaneous ostracod group from the Mid-Cretaceous of the south shelf of the Tethys sea. Journal of African Earth Sciences, 7, 691-702. 
Majoran, S. 1989. Mid-Cretaceous Ostracoda of northeastern Algeria. Fossils and Strata, 27, 1-67.

Maness, T. R. \& Kaesler, R.L. 1987. Ontogenetic changes in the carapace of Tyrrenocythere amnicola (Sars) a hemicytheridid ostracod. The University of Kansas Paleontological Contributions, 118, 1-15.

McKenzie, K. G. 1983. Shallow marine and freshwater Tethyan Ostracoda: Their usefulness for petroleum exploration. In Maddocks, R.F. (Ed), Proceedings of the Eighth International Symposium on Ostracoda. Application of Ostracoda, 35-50. Univ. Houston Geosc. USA.

McKenzie, K. G. \& Peypouquet, J-P. 1984. Oceanic palaeoenvironment of the Miocene Fyansford Formation from Fossil Beach near Mornington, Victoria, interpreted on the basis of Ostracoda. Alcheringa, 8, 291-303.

Neale, J. W. 1988. Ostracods and palaeosalinity reconstruction. In De Decker, P., Colin, J-P. and Peypouquet, J-P. (Eds.), Ostracoda in the Earth Sciences, 125-155. Elsevier Science Publishers B.V.

Peypouquet, J-P. 1977. Les Ostracodes et la connaissance des paléomilieux profonds. Application au Cénozoique de l'Atlantique nord-oriental. Thèse de doctorate d'état des Sciences Univ. Bordeaux I. 552, 1-448.

Peypouquet, J-P., Carbonel, P., Ducasse, P.O., Tölderer-Farmer, M. \& Lete, C. 1988. Environmentally cued polymorphism A theoretical and practical approach. A contribution to geology and to the understanding of ostracod evolution. In Hanai, T., Noriyuki, I., \& Ishizaki, K. (Eds.), Proceedings of the Ninth International Symposium on Ostracoda. Developments in Palaeontology and Stratigraphy, 11, 10031019. Kodansha, Elsevier.

Peypouquet, J-P., Grousset, F. \& Mourguiart, P. 1986. Paleooceanography of the Mesogean Sea based on ostracods of the northern Tunisian continental shelf between the Late Cretaceous and Early Paleogene. Geologische Rundschau, 75/1, 195-174.

Przibram, H. 1931. Connecting Laws of Animal Morphology. Four lectures held at the University of London., 1-62. University of London Press. London.

Reyment, R. A. 1963. Studies on Nigerian Upper Cretaceous and Lower Tertiary Ostracoda; Part 2, Danian, Paleocene and Eocene Ostracoda. Stockh. Contr. Geol., 10, 1-286

Reyment, R. A. 1965. Quantitative morphologic variation and classification of some Nigerian Paleocene Cytherellidae. Micropaleontology, 11, 457-465.

Reyment, R. A. 1966. Studies on Nigerian Upper Cretaceous and Lower Tertiary Ostracoda; Part 3, Stratigraphical paleoecological and biometrical conclusions. Stockh. Contr. Geol., 14, 1-151.

Reyment, R. A. 1984. Upper Cretaceous Ostracoda of North Central Spain. Bull. Geol. Instn. Univ. Uppsala. N.S. 10, 67110.

Reyment, R. A. 1988. Evolutionarily significant polymorphism in marine ostracods. In Hanai, T., Noriyuki, I., \& Ishizaki, K. (Eds.), Proceedings of the Ninth International Symposium on Ostracoda. Developments in Palaeontology and Stratigraphy, 11, 987-1001. Kodansha, Elsevier.

Reyment, R. A., Bookstein, K. G., McKenzie, K. G. \& Majoran, S. 1988. Ecophenotypic variation in Mutilus pumilus (Ostracoda) from Australia, studied by canonical variate analysis and tensor biometrics. J. micropalaeontol., 7, 11-20

Reyment, R. A. \& Brännström, B. 1962. Certain aspects of the physiology of Cypridopsis (Ostracoda, Crustacea), Stockh. Contr. Geol., 9, 209-242.
Rossi, V., Benassi, G. \& Menozzi, P. 1988. Ecology of parthenogenetic populations of Heterocypris incongruens. Programme and Abstracts of the Tenth International Symposium on Ostracoda, 52-53. Aberystwyth, Wales (2530 July 1988).

Schweitzer, P. N., Kaesler, R.L. \& Lohmann, G.P. 1986. Ontogeny and heterochrony in the ostracode Cavellina Coryell, from Lower Permian rocks in Kansas. Paleobiology, 12, 290-301.

Uffenorde, H. 1975. Dynamics in Recent marine benthonic ostracode assemblages in the Limski Kanal (northern Adriatic Sea). Bulletins of American Paleontology, 65, 147-166.

van Harten, D. 1983. Resource competition as a possible cause of sex ratio in benthic ostracodes. In Maddocks, R.F. (Ed.), Proceedings of the Eighth International Symposium on Ostracoda. Applications of Ostracoda, 568-580. Univ. Houston Geosc. USA.

Vivière, J-L. 1985. Les Ostracodes du Crétacé supérieur (Vraconien à Campanien basal) de la région de Tébessa (Algérie du Nord-Est): Stratigraphie, Paléoécologie, Systématique. Thèse 3e cycle, Univ. P. et. M. Curie, Paris. Mém. Sc. Terre, Paris VI, 1-261.

Whatley, R. C. 1983. The application of Ostracoda to paleoenvironmental analysis. In Maddocks, R.F. (Ed.), Proceedings of the Eighth International Symposium on Ostracoda. Applications of Ostracoda, 51-77. Univ. Houston Geosc. USA.

Williams, R. B. G. 1984. Introduction to Statistics for Geographers and Earth Scientists., 1-349. Macmillan Publishers Ltd.

Zahn, C. T. \& Roskies, R. Z. 1972. Fourier descriptors for plane closed curves. IEEE Trans. Computers, C-21(3), 269-281. 